NBER WORKING PAPER SERIES

\title{
EMPLOYEES' INVESTMENT DECISIONS ABOUT COMPANY STOCK
}

\author{
James J. Choi \\ David Laibson \\ Brigitte C. Madrian \\ Andrew Metrick \\ Working Paper 10228 \\ http://www.nber.org/papers/w10228
NATIONAL BUREAU OF ECONOMIC RESEARCH 1050 Massachusetts Avenue
Cambridge, MA 02138
January 2004

The views expressed herein are those of the authors and not necessarily those of the National Bureau of Economic Research.

(C)2003 by James J. Choi, David Laibson, Brigitte C. Madrian, and Andrew Metrick. All rights reserved. Short sections of text, not to exceed two paragraphs, may be quoted without explicit permission provided that full credit, including (C) notice, is given to the source. 
Employees' Investment Decisions about Company Stock

James J. Choi, David Laibson, Brigitte C. Madrian, and Andrew Metrick

NBER Working Paper No. 10228

January 2004

JEL No. E2, G1, G2, H3

\section{$\underline{\text { ABSTRACT }}$}

We study the relationship between past returns on a company's stock and the level of investment in that stock by the participants in that company's 401(k) plan. Using data on 94,191 plan participants, we analyze several different decision points: the initial fraction of savings allocated to company

stock, the changes in this fraction, and the reallocations of portfolio holdings across different asset classes. Like Benartzi (2001), we find that high past returns on company stock induce participants to allocate more of their contributions to company stock. We also find, however, that high returns on company stock have the opposite effect on reallocations of portfolio holdings, with high returns leading to shifts away from company stock and into other forms of equity. Overall, for company stock decisions, participants in our sample appear to be momentum investors when making contribution decisions and contrarian investors when making trading decisions.

James J. Choi

Department of Economics

Harvard University

Cambridge, MA 02138

james.choi@post.harvard.edu

David Laibson

Department of Economics

Harvard University

Cambridge, MA 02138

and NBER

dlaibson@harvard.edu
Brigitte C. Madrian

Department of Business and Public Policy

University of Pennsylvania

The Wharton School

Philadelphia, PA 19104

and NBER

bmadrian@courier-mail.wharton.upenn.edu

Andrew Metrick

Department of Finance

University of Pennsylvania

Wharton School

Philadelphia, PA 19104

and NBER

metrick@wharton.upenn.edu 


\section{Introduction}

Recent high-profile cases have illustrated the dangers of employee investment in company stock. These debacles are unlikely to be the last ones, or even the most severe. Companies with more than 50 percent of retirement assets in company stock are common, and fractions over 80 percent exist at such large companies as Procter \& Gamble, Anheuser-Busch, and Pfizer. ${ }^{1}$

The concentration of retirement wealth in company stock is a clear violation of diversification principles. Recently, several studies have quantified the economic costs of this concentration. Meulbroek (2002) uses a Sharpe-ratio approach and finds that the average diversification cost of company stock is about $42 \%$ of its value. Ramaswamy (2002) uses option-pricing techniques to compute the cost of insuring the extra risk of company stock. For a range of plausible parameter values, he finds that this insurance would be prohibitively expensive. ${ }^{2}$

Despite these high costs, companies continue to offer employee stock in their plans. There are many potential explanations for this behavior, but none are entirely satisfying. For example, employers may believe that stock compensation is inexpensive relative to cash, that there are strong incentive or morale effects, or that friendly employees will aid management in a takeover or other proxy battle. Mitchell and Utkus (2002) review these arguments and find little evidence to support them. The only explanation with any significant empirical support is tax-driven: dividends paid to certain employee ownership plans are tax-deductible at the corporate level. Liang and Weisbenner (2002) find a significant relationship between company stock fractions of total contributions and dividend payout. Nevertheless, this finding can explain only part 
of the puzzle, as many firms without any dividends still have significant employee ownership of company stock in their plans.

Even if employers offer their stock, it does not necessarily mean that employees must buy it. While many plans make matched contributions in company stock, and some of these plans restrict employees' rights to sell this stock for some period of time, there is still a significant amount of discretionary contributions to company stock. Benartzi (2001) was the first to investigate this behavior and provided an interesting explanation for it. Using a sample of about half of the S\&P 500 companies, he finds that discretionary contributions to company stock are positively correlated with the past returns on that stock. He posits that this correlation is due to employees' extrapolation of past returns when forming expectations about future returns. Liang and Weisbenner (2002) confirm this result for a larger number of companies over a longer time period.

The Benartzi (2001) and Liang and Weisbenner (2002) results use firm-level data drawn from SEC filings. These data provide the average contribution fraction to company stock for each firm. Thus, these studies use data for a large number of firms to analyze cross-sectional relationships between firm characteristics and employee discretionary contributions to company stock. Our analysis looks at some similar questions, but our approach is distinct and complementary: we use time-series variation in returns at three large firms' 401(k) plans from 1992 to 2000 to identify the effect of returns on the company stock choices of 94,191 plan participants. Our main goal is to use this timeseries variation to better understand the mechanisms by which past returns affect employee investment. Specifically, we attempt to measure the extent of "feedback" investing in company stock: to analyze whether participants are momentum or contrarian 
investors. Momentum investors trade with a trend, adding to their holdings after high returns; contrarian investors do the opposite. An active finance literature has developed in the past few years to look at the empirical evidence on feedback trading. ${ }^{3}$ By focusing on a salient asset class - company stock - we hope to make a contribution to this literature while at the same time providing useful insights for the policy debate on company-stock investment.

In the next section, we describe the data in detail and provide summary statistics about the three plans used in our study. The level of detail in these data allows us to study several decision points in the asset allocation decision. When an employee first enrolls in a 401(k) plan offered by her employer, that employee becomes a participant in the plan and must choose, first, how much of her salary to contribute and, second, how to allocate these contributions across the investment options offered by the plan sponsor. All of the plans studied in this paper offer the stock of the employer as one of these investment options.

In the third section, we study the other part of this initial enrollment decision, focusing on the relationship between the returns prior to the initial contribution decision ("initial prior returns") and the "initial contribution fraction" to an asset class. We find that the initial contribution fraction to company stock is significantly related to the past one-year returns on that stock. Those influential past returns include both the common market-wide component of returns and the company-specific component of returns. For both components, high returns induce participants to shift towards company stock and away from other equities. The net effect on total equity holding is much smaller, but the contributions are much less diversified within equities. 
Over time, many participants change their initial decisions. These changes provide another channel for past returns to affect contribution fractions. In the fourth section, we analyze the relationship between past returns and the direction of contribution changes. For this analysis, the returns are measured prior to the change, not prior to the initial decision. We again find a strong influence of past returns. Here, high levels of company-specific returns induce a substitution towards company stock and away from other equities, and a net positive substitution towards all equity.

Our final set of analyses focuses on the direct reallocation of portfolio holdings, which we call "trades." There, we study the relationship between the direction of trades into or out of an asset class and the prior returns on that asset class. Here, we find that high returns induce trades out of company stock and towards other equity, as participants seem to be engaging in profit-taking by selling their successful investments. We conclude with a summary of our results and a discussion of their implications.

\section{Data}

Our data are provided by Hewitt Associates, a large benefits administration and consulting firm. From Hewitt's roster of clients, we identified three large companies (which we denote as Alpha, Delta, and Gamma) that offered company stock as an investment option and obtained detailed data on individual participant in each plan. The data have two components. The first is panel data on every transaction that occurred in the plans since Hewitt took over their administration. These data go from January 4, 1993 to October 20, 1999 for Alpha; January 31, 1994 to January 26, 2000 for Delta; and April 3, 1996 to March 3, 2000 for Gamma. The second component of the data is cross-sections 
taken at year-ends 1998 and 1999 that include demographic, hire and enrollment dates, and balances information for all participants had positive balances or plan activity in 1998 or 1999. We will refer to December 31, 1999 as the "final date." None of these companies are financial services or technology companies. ${ }^{4}$

Table 1 gives demographic statistics for those participants in our sample who were active in the plans at the final date. (This is a subset of the 94,191 total employees that we observe.) The average plan balance for these participants is $\$ 89,172$. The most comparable cross-sectional data to ours is the EBRI/ICI sample of 401(k) plans, which covers about 35 percent of the assets in the 401(k) universe. Holden and VanDerhei (2001) report average plan balances at the end of 1999 broken down by plan size. They find that average plan balances are positively correlated with the number of participants in the plan, mostly because larger companies tend to have started plans earlier, thus giving more time for balances to be accumulated. For plans with greater than 10,000 participants-like all three of our plans - they report an average balance of $\$ 73,672$.

Table 2 breaks down the contribution fraction and asset holdings into three nondisjoint asset classes. Company stock contribution fractions are 16.6 percent at Alpha, 4.5 percent at Delta, 12.0 percent at Gamma, and 9.9 percent as a participant-weighted average across the three companies. The holdings in company stock are similar to the contribution fractions at Gamma, but are significantly higher at Alpha (31.5 percent versus 16.6 percent) and Delta ( 8.1 percent versus 4.5 percent). The disparity at Alpha is partly due to the fact that Alpha makes matching contributions in company stock and places some tenure restrictions on selling these contributions. Like most clients of Hewitt 
Associates, Delta and Gamma do not match in company stock and place no restrictions on the holdings of company stock.

These holdings fractions are somewhat lower than the national averages reported by Holden and VanDerwei (2001) from the EBRI/ICI database. They find that, among large plans (>5000 participants) with similar investment offerings to our sample companies, the average holding of company stock is 23.9 percent of the portfolio. Note, however, that many of the plans in this class of the EBRI/ICI sample are like company Alpha in that they match contributions in company stock and impose some trading restrictions on these matched contributions. Nevertheless, even Alpha has lower company stock holdings than the average company that matches in company stock.

While the main focus of the paper is on company stock, it is also useful to know the relationship between past returns and allocation to other asset classes. These relationships are not only interesting in themselves, but are also important for knowing whether changes in company stock investments crowd out other equities. We consider two other asset classes in the paper. "Total equity" includes all equity holdings, domestic and international, including company stock. "Other equity" is total equity minus company stock.

The paper studies the initial contribution fractions to these asset classes, the subsequent changes in these contribution fractions, and the trades across the classes. Before turning to these analyses, it is useful to examine the empirical frequency of changes and trades. Figure 1 plots the likelihood of ever having made a change to contribution fractions or a trade as a function of tenure in the plan. By three years after initial enrollment, 49.8 percent of participants have made at least one change to their 
initial contribution fraction, and 46.7 percent have made a trade. ${ }^{6}$ These two groups overlap significantly, so that their union comprises only 58.0 percent of the population. By six years after enrollment, these percentages are over 70 percent for each of the two activities separately, and 80.0 percent for either.

Figure 2 plots the frequency of trades per year for all individuals that have at least three years participation as of the final date. Within this whole group, 37.9 percent have never made a trade. The next highest grouping is between 0.26 and 0.50 trades per year, with 37.3 percent of participants falling into this range. Very few participants make more than 0.50 trades per year. Overall, these trading frequencies are somewhat higher than for the typical firm in the Hewitt universe, most likely because these firms were "early adopters" of the Internet channel for trading and other participant activities (Choi, Laibson, and Metrick (2002)).

\section{Initial contribution fractions}

We begin with an analysis of the initial contribution fraction. Our central tobit regression equation for this analysis is

$$
Y_{i}=\alpha+\beta X_{i}+\varepsilon_{i}
$$

where $Y_{i}$ is the fraction (censored below at 0 and above at 1 ) of company stock, other equity, or total equity out of the total contribution, $X_{i}$ is a vector of firm-level and participant-level characteristics that may explain the cross-sectional pattern of flow decisions, and $\varepsilon_{i}$ is the participant-level error term. While we employ panel-data notation to distinguish among participants and initial dates, these regressions use only one observation per participant. The sample includes every participant with positive balances 
or plan activity in 1998 or 1999. For each member of the sample, we include a single observation made on the date they first enrolled in their plan, and all explanatory variables for that participant $\left(X_{i}\right)$ are measured on that same date.

We include several firm-level variables in the $X_{i}$ vector. Our main variables of interest are the past returns on company stock and on the overall stock market. Since we would like to separate common shocks (stock market returns) and firm-specific shocks (company stock returns), we include two past return variables. SP500 is the past return for the S\&P 500 in the one year (253 trading days) preceding the enrollment of participant $i$. That is, if participant $i$ enrolls on date $t$, then $S P 500_{i}$ is the return from trading date $t-253$ to trading date $t-1$. CSTOCK $i$ is the excess return over the S\&P 500 for the company stock of participant $i$. Like SP500, it is measured over the preceding 253 trading days. Thus, all participants who enroll on the same date $t$ will have identical SP500 values; all participants who enroll on the same date $t$ at the same company will have identical CSTOCK values. For notational convenience, we drop the $i$ subscripts for the remainder of this discussion.

Previous research finds that investment behavior is also influenced by the variance of past returns. Thus, we include two variance measures in $X$. Std(SP500) and Std(CSTOCK) are the standard deviations of the daily returns on the S\&P 500 and company stock over the 253 trading days preceding the enrollment of participant $i$. Finally, we include a separate fixed effect and trend for each company. The regression constant is omitted.

We include several participant-level variables as elements of $X$. Many researchers have found that total equity fractions are related to age. The most common finding is a 
hump-shaped relationship between equity holdings and age, with equity fractions first increasing and then decreasing later in life, although consistent relationships across studies have been elusive. ${ }^{7}$ We include age and $a g e^{2}$ as elements of $X$. In addition, many studies show that overall equity holdings are positively related to salary; Holden and VanDerhei (2001) confirm this finding in the EBRI/ICI sample. For company stock, however, they find little relationship between salary and company stock fractions, with just a hint of slight negative tilt at the highest salary levels. Like EBRI, we do not have data on wealth, so we rely on salary as a proxy and include the log of annualized salary for the year of enrollment as an element of $X$.

Company stock contributions may also be related to job tenure. Workers with longer tenure at enrollment may differ from other participants along several dimensions. First, since they have been at the company longer, they may have more human capital dedicated to the company. This should induce lower contributions to company stock, other things equal. On the other hand, they may have a greater loyalty to the company and feel more of a duty to invest in company stock. Finally, workers who first participate later in their careers may have waited because they are less financially sophisticated. This lower sophistication may be correlated with poorer diversification and higher contributions to company stock. The relative importance of these different factors is an empirical question. In the yearend 1998 EBRI/ICI sample, Holden, VanDerhei, and Quick (2000) find a positive relationship. We include a variable, TENURE, which is the $\log$ of $1+$ job tenure (in years), as an element of $X$.

The results are summarized in Table 3 . The dependent variable is company stock in column 1 , other equity in column 2 , and total equity in column 3 . The results show a 
strong impact of past returns on the initial contribution fractions to company stock. The coefficient on both SP500 and CSTOCK is positive and significant when the dependent variable is company stock (column 1); conversely, the coefficients on these two variables are negative and significant when the dependent variable is other equity (column 2). These respective coefficients are positive but insignificant for total equity (column 3).

This pattern of results suggests that when company stock returns are high, newly enrolled participants contribute a higher fraction of their flows to company stock and a lower fraction of their flows to other equity; on net, the fraction of flows allocated to all equity (total equity) tends to cancel. Thus, these past returns - both the marketwide (SP500) and company-specific (CSTOCK) have mostly a compositional effect on overall equity holdings.

For the other independent variables, we find results consistent with previous studies. The coefficients on age and age (column 3), while not significant, are consistent with a hump-shape relationship between total equity fraction and age. The relationship between salary and total equity is positive and significant, while the relationship between salary and company stock fraction is negative and significant.

One possible criticism of these results is that the standard errors are understated. If firm-specific shocks induce correlated behavior across participants enrolling around the same time, then our assumption of cross-sectionally independent residuals would be violated, and our standard errors would be biased downward. For example, if firms change their communication strategies to new participants, then these new strategies could induce correlated behavior. In this case, we would think that we have more independent observations than we really do. 
Our regression specification controls for firm-specific differences in average behavior (with fixed effects) and for firm-specific changes in this average behavior over time (with trend variables for each firm), but to control for firm-specific shocks would require a specification of the correlation structure induced by such shocks. This is more structure than we are comfortable imposing. Instead, we perform a simple robustness check by assuming an extreme case: perfect correlation for all participants who enroll on the same day. To do this, we compute the average percentage allocated to each asset class by all participants who enrolled on each day. We then perform a separate time-series regression of these averages for each firm on the firm-specific independent variables used in equation (1). Furthermore, we allow for error correlation across days by computing Newey-West (1987) robust standard errors. Even in this extreme case, we find evidence that past returns affect contribution allocations. The results are summarized in the paragraph below; full tabular results are available from the authors.

The strongest evidence is for the company stock fraction, where two of the three firms show a positive and significant impact of past company stock returns on the company stock fraction, and one of the companies shows a positive and significant impact of past S\&P 500 returns. For other equity, the results are consistent with the participant-level evidence from Table 3: the coefficients on company stock are negative and significant for two firms, and the coefficients on S\&P 500 are negative (but insignificant) for all three firms. For total equity, these results appear to cancel, with no strong pattern to the coefficient signs. Thus, as for the individual-level results in Table 3, it appears that past returns play mostly a composition effect within total equity, with high 
past returns leading to higher fractions allocated to company stock and lower fractions allocated to other equity.

\section{Contribution Fraction Changes}

The preceding section focused on snapshots of flows and the impact of past returns on these snapshots. This section examines the determinants of the changes to these flows: How do past returns affect changes to flow fractions? We now shift attention away from the returns preceding enrollment to the returns preceding specific changes.

Table 4 summarizes the results of logit regressions for the company stock fraction (column 1), the other equity fraction (column 2), and the total equity fraction (column 3). The dependent variable is an indicator variable equal to one if the fraction is increased and zero otherwise. The explanatory variables remain the same as in the previous section, except that SP500 and CSTOCK are the returns for the year immediately preceding the contribution fraction change. The sample includes every change made by any participant who was active in the plans at year-ends 1998 or $1999 .{ }^{8}$

The results demonstrate more evidence of the powerful impact of past returns on participant behavior. As in the previous section, we find that the coefficient on CSTOCK is positive and significant for the company stock regressions (column 1). In this case, however, the coefficient is also positive (and nearly significant) for other equities, so it appears that company stock does not crowd out other equities when contributions are changed. Hence, the net effect of CSTOCK on total equity is positive and significant (column 3). Furthermore, another contrast with Table 3 is that the coefficient on SP500 is negative and significant for company stock (column 1) and is positive and significant 
for the total equity fraction. In this case, high returns on the marketwide component of company stock returns induce a shift away from company stock and towards other equity, with a new effect of shifts towards equity and away from other assets (column 3). Overall, participants act like momentum investors for total equity.

As with the analysis in the previous section, we have some concern that the coefficient standard errors in Table 4 may be understated due to firm-specific shocks. As a robustness check, we again collapse all the participant observations on each trading day down to a single observation for each firm. To do this, we construct a new dependent variable, $Y_{m n t}$, for each asset class $m$ (Company stock, other equity, or total equity) at each firm $n$ on every trading date $t . Y_{m n t}$ is a fraction where the numerator is the number of participants in firm $n$ who increased their flow fraction to asset $m$ on date $t$ minus the number of participants in firm $n$ who made an allocation change to any fund on date $t$ but didn't increase their flow fraction to asset $m$, and the denominator is all participants at firm $n$ who made any allocation change on date $t$. We then estimate separate time series regressions for each firm. The results are summarized in the paragraph below; full tabular results are available from the authors.

The main question is whether the qualitative results from Table 4 also hold here. The answer is yes. Several coefficients are significant and have the same sign as their analogues in Table 4. These significant coefficients are negative for one firm on SP500 and positive for two firms for CSTOCK in the company stock regressions; positive for two firms on SP500 and negative for one firm on CSTOCK in the other equity regressions; positive for one firm on SP500 in the total equity regressions. Meanwhile, no coefficients are significant with the opposite sign as their analogues in Table 4. 


\section{Trades}

The previous sections analyzed the determinants of contribution fractions - the investment flows - to company stock and other equity. Many researchers focus on flows because those data allow for the cleanest test of the impact of past returns on investment decisions. In contrast, studies of asset holdings and past returns suffer from an obvious problem: high returns through price appreciation on any given asset will tend to increase the fraction of that asset in overall holdings, even if investors take no action. Nevertheless, it is asset holdings, not flows, that drive the long-run distribution of wealth. In an extreme scenario, one could imagine that all participants rebalance their holdings on a regular basis, so that differences in flows cause only minor long-run differences in their portfolio allocations.

For example, consider a participant who wants to have five percent of his overall holdings in company stock. Suppose further that this participant allocated 20 percent to company stock at his initial enrollment because he had not yet decided to limit company stock to 5 percent of his overall portfolio. Now, in later years, he could change his contribution fraction in company stock to 5 percent, but he would still require periodic rebalances of his holdings to ensure that this five percent fraction is maintained. It may be the case that he finds it simpler to rebalance his holdings to 5 percent and ignore the flow component in the short run. If so, even though contribution fractions might appear to be influenced by returns prior to enrollment, we would not notice any long-run impact of these fractions on portfolio diversification. 
To examine this possibility, we perform several tests. First, we look at the rebalancing decision ("trades") with the same methods used to study changes in the flow fraction. We take every trade initiated by employees who had positive balances or plan activity in 1998 or 1999 and estimate a separate logit regression for each asset class, where the dependent variable takes on a value of one if the trade increased holdings in that asset class and zero otherwise. ${ }^{9}$

The results are summarized in Table 5. The key evidence is in column (1). Here, we see that returns one year prior to the trade on both components of company stock returns (CSTOCK and SP500) induce participants to trade out of company stock, but only for SP500 is there a significant effect. For both components, high returns induce participants to substitute away from company stock and towards other equities, with positive and significant coefficients on both components in column (2). These results are consistent with "profit-taking" behavior found in other studies (Odean (1998), Grinblatt and Keloharju (2001)), where investors tend to sell "winner" stocks and hold "loser" stocks. Somewhat paradoxically, the net effect on total equity is positive and significant for the CSTOCK component, perhaps because rising prices on company stock induce participants to feel wealthier and less risk-averse.

We next perform an analogous analysis at the firm level, using the same approach as in previous sections. The dependent variable is the number of participants who increased their holdings of the respective asset class in day $t$ minus the number of participants who made any trade but didn't increase their holdings of the respective asset class in day $t$, divided by the number of participants who made any trade in day $t$. We estimate separate regressions for each asset class for each firm. Even in this extreme case, 
we find evidence that past returns affect contribution allocations. The results are summarized in the paragraph below; full tabular results are available from the authors.

Consistent with the results of Table 5, we find that the coefficient on SP500 is negative and significant for one firm, and negative but insignificant for the other two. For other equity, we find that the coefficients on SP500 are positive and significant for all three firms. Overall, it appears that participants act as contrarians in their trades for company stock.

\section{Conclusion}

This paper studies the decisions of almost 100,000 individual 401(k) participants. Our goal is to better understand the determinants of employees' discretionary investment in company stock. The great detail in the data allows for an analysis at several different stages in the $401(\mathrm{k})$ process. Our main conclusion is that past returns matter for every stage. We find that high returns on company stock for the year prior to enrollment induce participants to make higher initial contributions to company stock. Furthermore, high returns over any one year period induce participants to increase these contribution fractions. High returns on company stock have the opposite effect on trading decisions: high past returns induce participants to substitute away from company stock and into other equities. Thus, participants are momentum investors when making decisions about investment flows but contrarian investors when making trading decisions. One caveat to our results is that our sample of three companies, while including many participants, is still small relative the universe of $401(\mathrm{k})$ participants, and has a relatively low level of company stock holdings. 
These results allow us to build on the important work of Benartzi (2001). Benartzi finds a positive relationship between past returns on company stock and current contributions to company stock, with the strongest results for past ten-year returns, and weaker results for shorter horizons. We would explain this result as the combination of several forces. First, when participants join, they are influenced by the past returns, including the past one-year return. Some participants never alter these initial contribution fractions, and so several distinct past years may seem influential at any point in time, but the influence of the most recent year will be limited. Second, some participants do make changes, but these changes are infrequent and fewer than 40 percent make changes in any given year. These changes are influenced by the immediate prior returns, but such prior returns are often far removed from the current year. Again, we see that the influence of the most recent year is limited. Taken together, the initial contributions and the contribution changes are both influenced by one-year returns, but these years are spread out over a long period. Then, when we look for a relationship between current contributions and past returns, the longer period appears better at the company level.

Our most interesting and policy-relevant findings are for the relationship between asset holdings and past returns. Absent frequent rebalancing, high returns on assets will tend to increase the allocation to these assets. Thus, it is very difficult to directly test for a relationship between asset holdings and the past returns on these assets. The best we can do is to try to infer these relationships by looking at the different decisions made by investors. Since most previous studies have used cross-sectional snapshots of holdings and contribution fractions, they have logically focused on the latter as the cleanest source of data. These studies find - as do we - that high past returns on company stock tend to 
increase contribution fractions to company stock. Using the time-series data in this paper, we see that trading decisions may work to mitigate some of this effect. Since high past returns induce participants to substitute out of company stock, the strong relationship between past returns and contributions is less dangerous for asset allocation than it might appear from these previous studies.

\section{References}

Agnew, Julie, Pietro Balduzzi, and Annika Sunden, 2002, Portfolio choice, trading, and returns in a large $401(\mathrm{k})$ plan, Working paper, Boston College.

Ameriks, John and Steve Zeldes, 2001, "How do household portfolios vary with age", Working paper, Columbia University.

Benartzi, Shlomo, 2001, "Excessive extrapolation and the allocation of company stock to retirement accounts", Journal of Finance 56(5), 1747-1764.

Choi, James J, David Laibson, and Andrew Metrick, 2002 "How Does the Internet Affect Trading? Evidence from Investor Behavior in 401(k) Plans", Journal of Financial Economics 64(3), 397-421.

Choi, James J., David Laibson, Brigitte Madrian, and Andrew Metrick, 2002, "Defined contribution pensions: Plan rules, participant choices, and the path of least resistance", in James Poterba ed., Tax Policy and the Economy, MIT Press, 67113.

Goetzmann, William N and Massimo Massa, 2002, "Daily Momentum and Contrarian Behavior of Index Fund Investors", Journal of Financial and Quantitative Analysis. 37 (3), 375-89.

Grinblatt, Mark, and Matti Keloharju, 2001, "What Makes Investors Trade?", Journal of Finance, 56(2), 589-616.

Holden, Sarah and Jack VanDerhei, 2001, “401(k) plan asset allocation, account balances, and loan activity in 1999", Investment Company Institute Perspective $7(1)$.

Holden, Sarah, Jack VanDerhei, and Carol Quick, 2000, "401(k) plan asset allocation, account balances, and loan activity in 1998", Investment Company Institute Perspective 6(1). 
Liang, Nellie and Scott Weisbenner, 2002, "Investor behavior and the purchase of company stock in 401(k) plans - The importance of plan design", Working paper, University of Illinios.

Mitchell, Olivia S. and Stephen P. Utkus, 2002, Company stock and retirement plan diversification, Pension Research Council Working Paper 2002-4, The Wharton School of the University of Pennsylvania

Odean, Terrance, 1998, “Are Investors Reluctant to Realize Their Losses?” Journal of Finance. 53(5), 1775-98.

Muelbroek, Lisa, 2002, “Company stock in pension plans: how costly is it?", Harvard Business School working paper 02-058.

Ramaswamy, Krishna, 2002, "Company stock and DC plan diversification", Working paper, The Wharton School of the University of Pennsylvania

Schultz, Ellen E. and Theo Francis, 2002, "Companies' hot tax break: 401(k)s", Wall Street Journal, January $31^{\text {st }} 2002$, Page C1.

*We thank Hewitt Associates for their help in providing the data. We are particularly grateful to Lori Lucas and Jim McGhee, two of our many contacts at Hewitt. Choi acknowledges financial support from a National Science Foundation Graduate Research Fellowship. Laibson and Madrian acknowledge financial support from the National Institute on Aging (R01-AG-16605 and R29-AG-013020 respectively). Laibson also acknowledges financial support from the MacArthur Foundation.

${ }^{1}$ The original source for these percentages is Schultz and Francis (2002), as reported by Mitchell and Utkus (2002).

${ }^{2}$ For example, he notes that "a 25 -year-old employee who wanted to buy an insurance policy on company stock that he cannot reallocate until he is 50 years old" would have to pay $\$ 739$ per $\$ 1000$ of value.

${ }^{3}$ For a discussion of this literature, see Goetzmann and Massa (2002). 
${ }^{4}$ Several other recent papers have used participant-level panel data to explore different aspects of 401(k) investment behavior, but none of these papers have focused on company stock. See Agnew, Balduzzi and Sunden (2002), Ameriks and Zeldes (2001), Choi, Laibson, Madrian, and Metrick (2002), and Choi, Laibson and Metrick (2002).

${ }^{5}$ Omitting international funds from the definitions of other equity and total equity does not qualitatively alter the results of the paper. For balanced funds, we include the fraction of that fund targeted to equities.

${ }^{6}$ These figures omit trades and allocation changes that were initiated by the plan administrators.

${ }^{7}$ Ameriks and Zeldes (2001) survey this evidence and discuss some new evidence from a sample of TIAA-CREF participants.

${ }^{8}$ We omit changes made at Gamma in November 1996 and April 1998 because numerous funds were shut down in those months, so allocation changes then may have been due to the plan administration automatically shifting contributions away from the closed funds.

${ }^{9}$ We omit trades that were initiated by the plan administration. 


\section{Table 1}

Demographic Summary Statistics

This table presents summary statistics for the data on 401(k) participants. Unless otherwise noted, all figures are as of year-end 1999.

\begin{tabular}{lc}
\hline Average age & 45.0 \\
Average salary & $\$ 55,830$ \\
Average tenure at company & 15.8 years \\
Average elected contribution rate & $8.73 \%$ \\
Average plan balance & $\$ 89,172$ \\
Percent who traded in 1999 & $39.3 \%$ \\
Total companies & 3 \\
Total participants (all years) & 94,191 \\
\hline
\end{tabular}

Source: Authors' calculations. 
Table 2

Equity Summary Statistics

This table presents the proportion of discretionary contributions and year-end balances that were in equities in 1999.

\begin{tabular}{|c|c|c|c|c|}
\hline & & $\begin{array}{c}\text { Company stock } \\
\text { (1) }\end{array}$ & $\begin{array}{c}\text { Other equities } \\
(2) \\
\end{array}$ & $\begin{array}{c}\text { All equities } \\
(3)\end{array}$ \\
\hline Company Alpha & $\begin{array}{l}\text { Contributions } \\
\text { Holdings }\end{array}$ & $\begin{array}{l}16.6 \% \\
31.5 \%\end{array}$ & $\begin{array}{l}51.8 \% \\
39.7 \%\end{array}$ & $\begin{array}{l}68.4 \% \\
71.2 \%\end{array}$ \\
\hline Company Delta & $\begin{array}{l}\text { Contributions } \\
\text { Holdings }\end{array}$ & $\begin{array}{l}4.5 \% \\
8.1 \%\end{array}$ & $\begin{array}{l}49.6 \% \\
48.6 \%\end{array}$ & $\begin{array}{l}54.1 \% \\
56.7 \%\end{array}$ \\
\hline Company Gamma & $\begin{array}{l}\text { Contributions } \\
\text { Holdings }\end{array}$ & $\begin{array}{l}12.0 \% \\
11.4 \%\end{array}$ & $\begin{array}{l}52.1 \% \\
53.5 \%\end{array}$ & $\begin{array}{l}64.1 \% \\
64.8 \%\end{array}$ \\
\hline Total & $\begin{array}{c}\text { Contributions } \\
\text { Holdings }\end{array}$ & $\begin{array}{l}9.9 \% \\
17.7 \%\end{array}$ & $\begin{array}{l}50.8 \% \\
46.0 \%\end{array}$ & $\begin{array}{l}60.7 \% \\
63.6 \%\end{array}$ \\
\hline
\end{tabular}

Source: Authors' calculations 
Table 3

Initial Contribution Allocation, 11/30/1992 - 2/17/2000, as a Function of Asset Returns Prior to Plan Enrollment

The dependent variable in column 1 is the percent of the participant's first payroll contribution that went to company stock, the dependent variable in column 2 is the percent of the participant's first payroll contribution that went to other equities, and the dependent variable in column 3 is the percent of the participant's first payroll contribution that went to all equities. Coefficients shown are for tobit regressions censored at 0 and 1. SP500 is the cumulative return on the S\&P 500 for the 253 trading days prior to the participant's enrollment in the plan. CSTOCK is the cumulative return in excess of the S\&P 500 on company stock for the 253 trading days prior to participant enrollment. Std(SP500) and Std(Cstock) are the standard deviations of the S\&P 500 and company stock returns, respectively, over the 253 trading days prior to the participant's enrollment. Salary is the log of annual salary in the year of enrollment (in 1999 CPI-deflated dollars), Age is the participant's age at the time of enrollment, $\mathrm{Age}^{2}$ is the square of Age, and Tenure is the log of one plus the years between the participant's original hire date and plan enrollment date. Company Trend $x$ is the years between December 31, 1980 and the participant's enrollment if the participant is in Company $x$, and zero otherwise. $\sigma(\varepsilon)$ is the standard deviation of the latent variable's residual. Coefficients on fixed-effect company dummies and a constant are not shown. Standard errors are reported in parentheses below the point estimates.

\begin{tabular}{|c|c|c|c|}
\hline & $\begin{array}{c}\text { Company stock } \\
\text { (1) }\end{array}$ & $\begin{array}{l}\text { Other equities } \\
\text { (2) }\end{array}$ & $\begin{array}{c}\text { All equities } \\
\text { (3) }\end{array}$ \\
\hline SP500 & $\begin{array}{l}0.80 * * \\
(0.07)\end{array}$ & $\begin{array}{l}-0.46^{* *} \\
(0.06)\end{array}$ & $\begin{array}{c}0.04 \\
(0.07)\end{array}$ \\
\hline CSTOCK & $\begin{array}{l}0.45^{* *} \\
(0.04)\end{array}$ & $\begin{array}{l}-0.14 * * \\
(0.03)\end{array}$ & $\begin{array}{c}0.07 \\
(0.04)\end{array}$ \\
\hline Std(SP500) & $\begin{array}{r}-12.76^{*} \\
(5.16)\end{array}$ & $\begin{array}{l}-3.36 \\
(4.10)\end{array}$ & $\begin{array}{l}-2.21 \\
(4.79)\end{array}$ \\
\hline$S t d(C S T O C K)$ & $\begin{array}{c}-12.13^{* *} \\
(3.55)\end{array}$ & $\begin{array}{l}-2.47 \\
(2.91)\end{array}$ & $\begin{array}{c}0.39 \\
(3.41)\end{array}$ \\
\hline Salary & $\begin{array}{l}-0.08^{* *} \\
(0.01)\end{array}$ & $\begin{array}{l}0.16^{* *} \\
(0.01)\end{array}$ & $\begin{array}{l}0.11^{* *} \\
(0.01)\end{array}$ \\
\hline Age / 100 & $\begin{array}{c}0.02 \\
(0.50)\end{array}$ & $\begin{array}{c}0.26 \\
(0.41)\end{array}$ & $\begin{array}{c}0.24 \\
(0.48)\end{array}$ \\
\hline $\mathrm{Age}^{2} / 1000$ & $\begin{array}{c}0.04 \\
(0.06)\end{array}$ & $\begin{array}{l}-0.09 \\
(0.05)\end{array}$ & $\begin{array}{l}-0.05 \\
(0.06)\end{array}$ \\
\hline Tenure & $\begin{array}{c}0.02 * \\
(0.01)\end{array}$ & $\begin{array}{l}-0.06^{* *} \\
(0.01)\end{array}$ & $\begin{array}{l}-0.04 * * \\
(0.01)\end{array}$ \\
\hline Company Trend $\alpha$ & $\begin{array}{l}0.02 * * \\
(0.01)\end{array}$ & $\begin{array}{l}0.02 * * \\
(0.00)\end{array}$ & $\begin{array}{l}0.02 * * \\
(0.00)\end{array}$ \\
\hline Company Trend $\delta$ & $\begin{array}{l}-0.08^{* *} \\
(0.01)\end{array}$ & $\begin{array}{l}0.17 * * \\
(0.01)\end{array}$ & $\begin{array}{l}0.14^{* *} \\
(0.01)\end{array}$ \\
\hline Company Trend $\gamma$ & $\begin{array}{l}0.07 * * \\
(0.02)\end{array}$ & $\begin{array}{l}0.06^{* *} \\
(0.02)\end{array}$ & $\begin{array}{l}0.08^{* *} \\
(0.02)\end{array}$ \\
\hline$\sigma(\varepsilon)$ & $\begin{array}{l}0.76^{* *} \\
(0.01)\end{array}$ & $\begin{array}{l}0.69 * * \\
(0.01)\end{array}$ & $\begin{array}{l}0.80 * * \\
(0.01)\end{array}$ \\
\hline
\end{tabular}

* Significant at the 5 percent level

** Significant at the 1 percent level Source: Authors' calculations. 
Table 4

Probability of Increasing Contribution Fraction, 12/31/1992 - 3/3/2000, as a Function of Asset Returns Prior to the Election Change

This table presents the results of a binary logit regression of the probability a participant increases the fraction of his or her contribution to company stock (column 1), other equities (column 2), and all equities (column 3), conditional on making a change to his or her contribution allocations. SP500 is the cumulative return on the S\&P 500 for the 253 trading days prior to the participant's first contribution after an election change. CSTOCK is the cumulative return in excess of the S\&P 500 on company stock for the 253 trading days prior to the post-change contribution. Std(SP500) and Std(CSTOCK) are the standard deviations of the S\&P 500 and company stock returns, respectively, over the 253 trading days prior to the post-change contribution. Salary is the log of annual salary in the year of the post-change contribution, and Total Balances is the log of total balances in the plan in the calendar month prior to the change, both in 1999 CPI-deflated dollars. $A g e$ is the participant's age at the time of the post-change contribution, $A g e^{2}$ is the square of $A g e$, and Tenure is the log of one plus the years between the participant's original hire date and the post-change contribution. Company Trend $x$ is the years between December 31, 1980 and the participant's post-change contribution if the participant is in company $x$, and zero otherwise. Coefficients on fixed-effect company dummies and a constant are not shown. Standard errors are reported in parentheses below the point estimates. Source: Authors' calculations.

\begin{tabular}{|c|c|c|c|}
\hline & $\begin{array}{c}\text { Company stock } \\
\text { (1) }\end{array}$ & $\begin{array}{l}\text { Other equities } \\
\text { (2) }\end{array}$ & $\begin{array}{c}\text { All equities } \\
\text { (3) }\end{array}$ \\
\hline SP500 & $\begin{array}{l}-2.09 * * \\
(0.10)\end{array}$ & $\begin{array}{l}2.85^{* *} \\
(0.08)\end{array}$ & $\begin{array}{l}1.02 * * \\
(0.08)\end{array}$ \\
\hline Cstock & $\begin{array}{l}0.59^{* *} \\
(0.04)\end{array}$ & $\begin{array}{c}0.06 \\
(0.03)\end{array}$ & $\begin{array}{l}0.23 * * \\
(0.03)\end{array}$ \\
\hline $\operatorname{Std}(S P 500)$ & $\begin{array}{c}-148.70^{* * *} \\
(5.45)\end{array}$ & $\begin{array}{l}39.67 * * \\
(4.58)\end{array}$ & $\begin{array}{c}-47.97 * * \\
(4.60)\end{array}$ \\
\hline Std(Cstock) & $\begin{array}{c}1.62 \\
(3.97)\end{array}$ & $\begin{array}{l}-5.40 \\
(3.42)\end{array}$ & $\begin{array}{l}16.49^{* *} \\
(3.40)\end{array}$ \\
\hline Salary & $\begin{array}{l}-0.14^{*} \\
(0.02)\end{array}$ & $\begin{array}{c}0.02 \\
(0.02)\end{array}$ & $\begin{array}{l}-0.09^{* *} \\
(0.02)\end{array}$ \\
\hline Total Balances & $\begin{array}{l}-0.14 * * \\
(0.01)\end{array}$ & $\begin{array}{l}-0.08^{* *} \\
(0.01)\end{array}$ & $\begin{array}{l}-0.13 * * \\
(0.01)\end{array}$ \\
\hline Age / 100 & $\begin{array}{l}2.66 * * \\
(0.69)\end{array}$ & $\begin{array}{l}3.73 * * \\
(0.58)\end{array}$ & $\begin{array}{l}4.18^{* *} \\
(0.58)\end{array}$ \\
\hline $\mathrm{Age}^{2} / 1000$ & $\begin{array}{l}-0.23 * * \\
(0.08)\end{array}$ & $\begin{array}{l}-0.47 * * \\
(0.07)\end{array}$ & $\begin{array}{l}-0.40^{* *} \\
(0.07)\end{array}$ \\
\hline Tenure & $\begin{array}{l}-0.01 \\
(0.01)\end{array}$ & $\begin{array}{l}0.04 * * \\
(0.01)\end{array}$ & $\begin{array}{l}0.18^{* *} \\
(0.01)\end{array}$ \\
\hline Company Trend $\alpha$ & $\begin{array}{l}0.40^{* *} \\
(0.01)\end{array}$ & $\begin{array}{l}-0.36^{* *} \\
(0.01)\end{array}$ & $\begin{array}{l}-0.20 * * \\
(0.01)\end{array}$ \\
\hline Company Trend $\delta$ & $\begin{array}{c}0.02 \\
(0.01)\end{array}$ & $\begin{array}{l}-0.10^{* *} \\
(0.01)\end{array}$ & $\begin{array}{l}-0.02 * * \\
(0.01)\end{array}$ \\
\hline Company Trend $\gamma$ & $\begin{array}{l}0.22 * * \\
(0.01)\end{array}$ & $\begin{array}{l}-0.00 \\
(0.01)\end{array}$ & $\begin{array}{l}-0.23 * * \\
(0.01)\end{array}$ \\
\hline
\end{tabular}

* Significant at the 5 percent level

** Significant at the 1 percent level Source: Authors' calculations. 


\section{Table 5}

Probability of Trading into Asset Class, 1/4/1993 - 3/6/2000, as a Function of Asset Returns Prior to Trade

This table presents the results of a binary logit regression of the probability a participant makes a trade increasing his or her holdings in company stock (column 1), other equities (column 2), or all equities (column 3), conditional on the participant trading. SP500 is the cumulative return on the S\&P 500 for the 253 trading days prior to the trade. CSTOCK is the cumulative returns in excess of the S\&P 500 on company stock for the 253 trading days prior to the trade. Std(SP500) and Std(CSTOCK) are the standard deviations of the S\&P 500 and company stock returns, respectively, over the 253 trading days prior to the trade. Salary is the log of annual salary in the year of the trade, and Total Balances is the log of total balances in the plan on the day of the trade, both in 1999 CPI-deflated dollars. Age is the participant's age at the time of the post-change contribution, $\operatorname{Age}^{2}$ is the square of Age, and Tenure is the log of one plus the years between the participant's original hire date and the trade date. Company Trend $x$ is the years between December 31, 1980 and the participant's trade if the participant is in company $x$, and zero otherwise. Coefficients on fixed-effect company dummies and a constant are not shown. Standard errors are reported in parentheses below the point estimates.

\begin{tabular}{|c|c|c|c|}
\hline & $\begin{array}{c}\text { Company stock } \\
\text { (1) }\end{array}$ & $\begin{array}{c}\text { Other equities } \\
\text { (2) }\end{array}$ & $\begin{array}{c}\text { All equities } \\
\text { (3) }\end{array}$ \\
\hline SP500 & $\begin{array}{l}-2.18^{* *} \\
(0.06)\end{array}$ & $\begin{array}{l}2.31^{* *} \\
(0.05)\end{array}$ & $\begin{array}{c}0.09 \\
(0.05)\end{array}$ \\
\hline CSTOCK & $\begin{array}{l}-0.01 \\
(0.02)\end{array}$ & $\begin{array}{l}0.31^{* *} \\
(0.02)\end{array}$ & $\begin{array}{l}0.07 * * \\
(0.02)\end{array}$ \\
\hline Std(SP500) & $\begin{array}{c}-159.70 * * \\
(4.24)\end{array}$ & $\begin{array}{l}71.28^{* *} \\
(3.86)\end{array}$ & $\begin{array}{c}-62.22 * * \\
(3.71)\end{array}$ \\
\hline $\operatorname{Std}(C S T O C K)$ & $\begin{array}{c}-36.62 * * \\
(2.33)\end{array}$ & $\begin{array}{c}-20.47 * * \\
(2.26)\end{array}$ & $\begin{array}{c}-26.88^{* *} \\
(2.14)\end{array}$ \\
\hline Salary & $\begin{array}{l}0.04 * * \\
(0.01)\end{array}$ & $\begin{array}{l}0.08^{* *} \\
(0.01)\end{array}$ & $\begin{array}{c}0.02 \\
(0.01)\end{array}$ \\
\hline Total Balances & $\begin{array}{l}-0.07 * * \\
(0.01)\end{array}$ & $\begin{array}{l}-0.02 * * \\
(0.00)\end{array}$ & $\begin{array}{l}-0.03 * * \\
(0.00)\end{array}$ \\
\hline Age / 100 & $\begin{array}{l}4.47^{* *} \\
(0.56)\end{array}$ & $\begin{array}{l}-2.83 * * \\
(0.50)\end{array}$ & $\begin{array}{l}1.24 * * \\
(0.48)\end{array}$ \\
\hline$A g e^{2} / 1000$ & $\begin{array}{l}-0.52 * * \\
(0.06)\end{array}$ & $\begin{array}{l}0.26^{* *} \\
(0.05)\end{array}$ & $\begin{array}{l}-0.09 \\
(0.05)\end{array}$ \\
\hline Tenure & $\begin{array}{l}0.07 * * \\
(0.01)\end{array}$ & $\begin{array}{l}-0.05^{* *} \\
(0.01)\end{array}$ & $\begin{array}{l}0.03 * * \\
(0.01)\end{array}$ \\
\hline Company Trend $\alpha$ & $\begin{array}{l}0.50^{* *} \\
(0.01)\end{array}$ & $\begin{array}{l}-0.26^{* *} \\
(0.01)\end{array}$ & $\begin{array}{l}0.15^{* *} \\
(0.01)\end{array}$ \\
\hline Company Trend $\delta$ & $\begin{array}{l}0.10^{* *} \\
(0.01)\end{array}$ & $\begin{array}{l}-0.12 * * \\
(0.01)\end{array}$ & $\begin{array}{l}0.05^{* *} \\
(0.01)\end{array}$ \\
\hline Company Trend $\gamma$ & $\begin{array}{l}0.56^{* *} \\
(0.02)\end{array}$ & $\begin{array}{l}-0.26^{* *} \\
(0.01)\end{array}$ & $\begin{array}{l}0.05^{* *} \\
(0.01)\end{array}$ \\
\hline
\end{tabular}

* Significant at the 5 percent level

** Significant at the 1 percent level

Source: Authors' calculation 


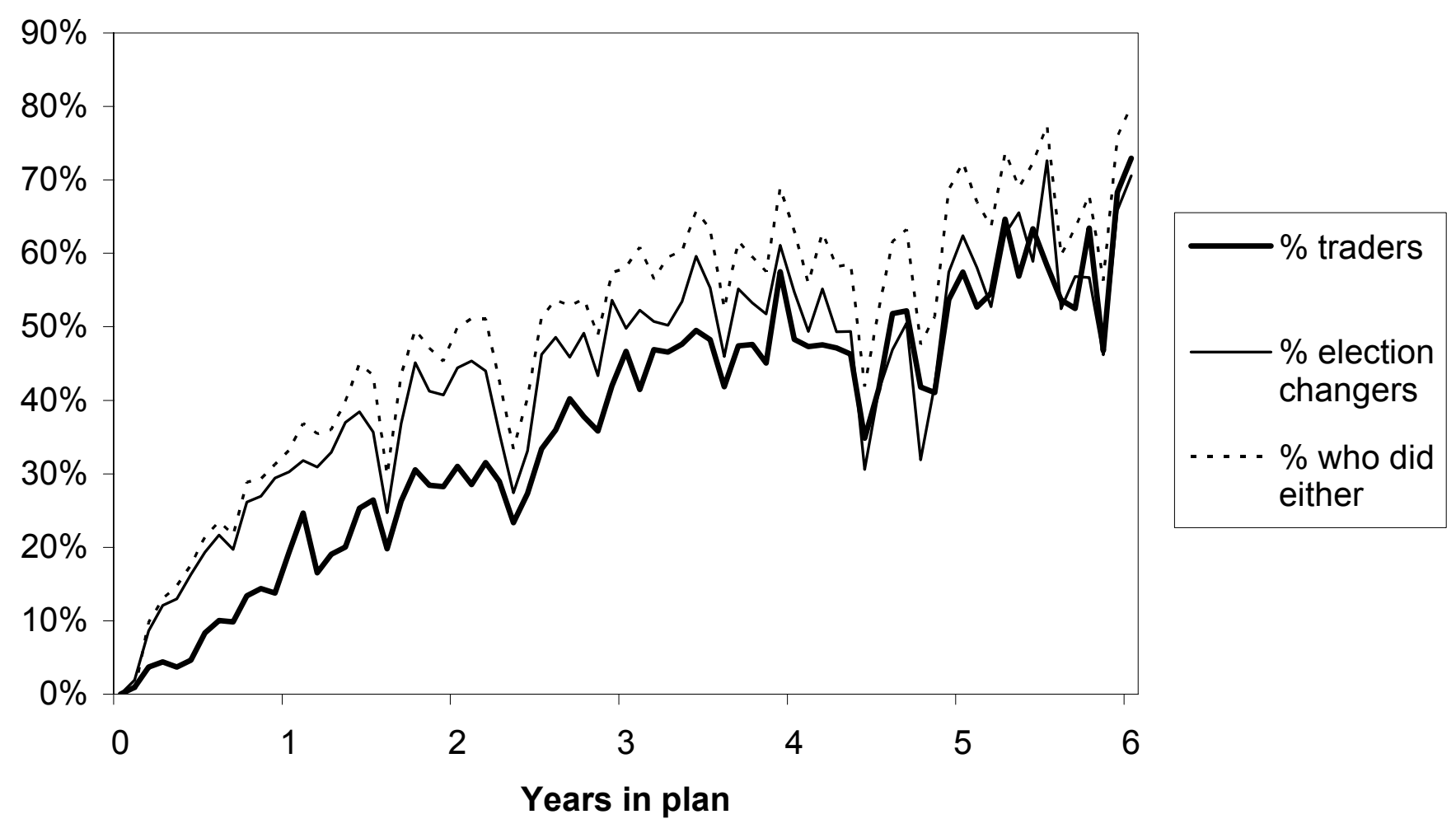

Figure 1. Likelihood of trading, changing elections, or doing either at least once, by tenure in plan, 12/31/1992 - 3/6/2000. We examine all people for whom we have data since their initial enrollment in the plans. The graph depicts the percent of participants who have made at least one trade, changed their discretionary contribution allocations at least once, or done either, plotted against the number of years we observe them in the plan. Source: Authors' calculations. 


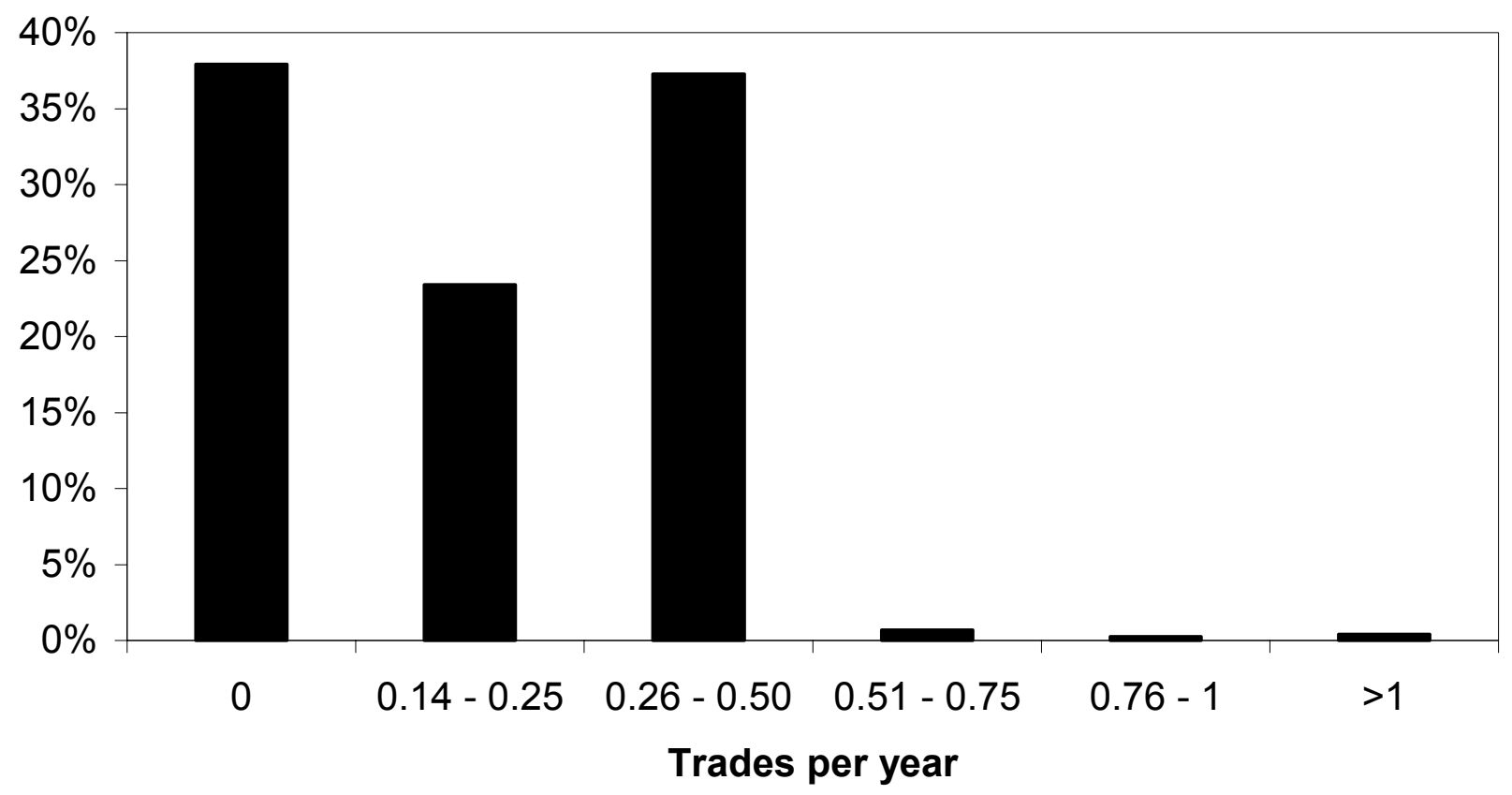

Figure 2. Histogram of participant trades per year, 1999 participants. We examine all people who are active in the plans as of year-end 1999 and who have been participating for at least three years. We divide the total number of times a participant has traded in our data by the number of years we observe the participant. The graph is a histogram of this ratio. Source: Authors' calculations. 